九州大学学術情報リポジトリ

Kyushu University Institutional Repository

\title{
Effect of Salt Concentrations on the Hydraulic conductivity of the MIxtures of Basalt soil and various Bentonites
}

Mishra, Anil Kumar

Graduate School of Bioresource and Bioenvironmental Sciences, Kyushu University

Ohtsubo, Masami

Department of Bioresource and Environmental Science, Kyushu University

Li, Loretta

The University of British Columbia, Canada

Higashi, Takahiro

Department of Bioresource and Environmental Science, Kyushu University

https://doi.org/10.5109/4707

出版情報: 九州大学大学院農学研究院紀要. 51 (1)，pp.37-43，2006-02-01. Faculty of Agriculture， Kyushu University

バージョン :

権利関係 : 


\title{
Effect of Salt Concentrations on the Hydraulic conductivity of the Mixtures of Basalt soil and various Bentonites
}

\author{
Anil Kumar MISHRA ${ }^{1 *}$, Masami OHTSUBO ${ }^{2}$, Loretta LI $^{3}$ \\ and Takahiro HIGASHI ${ }^{2}$
}

\author{
Laboratory of Soil Environmental Engineering, Division of Regional Environmental Science, \\ Department of Bioresource and Environmental Science, Faculty of Agriculture, \\ Kyushu University, Fukuoka-812-8581, Japan \\ (Received October 28, 2005 and accepted November 16, 2005)
}

\begin{abstract}
The present paper describes the influence of the various concentrations of $\mathrm{NaCl}$ and $\mathrm{CaCl}_{2}$ on hydraulic conductivity of the mixture of basalt soil and four different bentonites in the proportion of 100:20 by dry weight. The comparison of hydraulic conductivity $(k)$ for a given salt solution on a particular soil mixture shows that the $k$ decreased with decreasing the salt concentration. The decrease in $k$ with a decrease in salt concentration can be attributed to increase in diffuse double thickness. The comparison of $k$ for different salt solution shows that the divalent cation had more effect compared to the monovalent cation. However at $1 \mathrm{~mol}_{\mathrm{c}} \mathrm{L}$ concentration almost an equal value of $k$ was observed. With increasing the salt concentration from 0 to $0.1 \mathrm{~mol} / \mathrm{L}$, the $k$ changed significantly which was more prominent for the sample with $\mathrm{CaCl}_{2}$ solution. The results show that for a particular salt concentration mixture with higher liquid limit exhibited a lower $k$. However with increasing the salt concentration, the liquid limit converged and also the $k$.
\end{abstract}

Key words: Clay, permeability, salt solution, liquid limit, swelling, diffuse double layer thickness

\section{INTRODUCTION}

At the disposal sites of hazardous waste the concentration of the various harmful substances could exceed the concentration level that can be accepted from an environmental and health standpoint of view. The main problem is to reduce the production of dangerous leachate to such levels that the external concentration will not reach unacceptable values. This problem can be solved in several ways, one being the use of low permeable clay barriers. To prevent the ground water contamination by leachate from the waste, barriers with a low hydraulic conductivity are used as part of waste containment systems. Where suitable low hydraulic conductivity soils are not locally available, such a material can be produced by adding bentonite to a native soil. Such bentonite improved soils are used as a component of landfill liner systems.

When bentonite-soil mixtures are used for landfill liners and environmental containment barriers, they must limit the hydraulic flow. Presence of bentonite, which primarily composed of mineral montmorillonite, gives the lower value of hydraulic conductivity to the liner material. The small particle size, interlayer swelling, and thick layer of bound water associated with

\footnotetext{
1 Laboratory of Soil Environmental Engineering, Division of Regional Environmental Science, Department of Bioresource and Environmental Science, Graduate school of Bioproduction and Environmental Sciences, Kyushu University

2 Laboratory of Soil Environmental Engineering, Division of Regional Environmental Science, Department of Bioresource and Environmental Science, Kyushu University

${ }^{3}$ Department of Civil Engineering, The University of British Columbia, Vancouver, B.C, Canada

* Corresponding author (E-mail: anilk_iisc@yahoo.co.in)
}

montmorillonite particles provides bentonite with a low hydraulic conductivity to water (Mesri and Olson 1971).

The performance of a bentonite depends upon several factors, which includes the mineralogical composition, the surface area, the surface charge deficiency of the bentonite and the composition of the exchangeable complex. In general, the performance of the bentonite increases with increase in the montmorillonite content and the surface area (i.e. decrease in the particle size). The performance also increases with an increase in the sodium $\left(\mathrm{Na}^{+}\right)$percentage on the exchange complex. The effect of these factors on the quality of bentonite is reflected in an increase in the cation exchange capacity, an increase in the plasticity, an increase in the swell capacity in the presence of water, and a decrease in the hydraulic conductivity when permeated with water.

However, when the bentonite comes in contact with the salt solution, these same factors make it sensitive to chemical interaction which leads to an increase hydraulic conductivity (Gleason et al. 1997; Petrov et al 1997; Ruhl and Daniel 1997).

With the growing economy of Japan the generation of municipal solid waste (MSW) has reached 50 million tones per year. Due to limited availability of space $80 \%$ of this waste has been incinerated with the residue of fly ash and bottom ash (Hanashima and Furuichi, 2000). These flyash and bottom ash are disposed in controlled landfills having a chemical compatible clay liner with a hydraulic conductivity of $<1 \times 10^{-6} \mathrm{~cm} / \mathrm{sec}$. Fly ash and bottom ash mostly contains cations like $\mathrm{Na}^{+}$and $\mathrm{Ca}^{2+}$. Once it comes in contact with water, these water soluble cations moves into the clay liner and changes the properties of liner material.

For engineered landfill sites, the performance of soil liners is based on retention capacity and low hydraulic 
conductivity, which could be affected by the MSW fly ash leachate composition, in particular concentrations of cations (Mitchell 1994, Yong 1999, Warith 1987, Quigley et al 1987, 1988). Salt could affect the hydraulic conductivity of the soil liner and reduces the adsorption capacity of the heavy metals onto the soil liner (Yong and Sheremata 1991), in turn reducing the useful life of the liner. To design a secure soil liner, it is important to have a better understanding of the type and concentration of ion species that leach from the MSW ash.

Numerous attempts have been made to study the effect of these salt solutions on the bentonite alone. However in real situation a mixture of the locally available soil and bentonite is used as clay liner material. Many researchers have carried out their research work only on a particular bentonite while actually in the filed the quality and the type of bentonites vary from place to place. In addition to this the permeability test commonly used is not only time consuming but also expensive. The consolidometer permeameters system offers the means for quantitatively assessing the effect of chemical interaction on the permeability of clays (Madsen 1994). Many investigators (Newland and Alley 1960, Mesri and Olson 1971, Budhu et al 1991, Sivapullaiah et al 2000) have adopted this method, which gives quite satisfactory result of permeability as compare to the calculated values (Terzaghi 1923, Casagrande and Fadum 1944), however this method generally underestimates the value of hydraulic conductivity compared with field value (Taylor 1942, Mitchell and Madson 1987). The purpose of this investigation was to study the change in the hydraulic conductivity of mixtures of basalt and bentonites of different qualities due to permeation of salt such as $\mathrm{NaCl}$ and $\mathrm{CaCl}_{2}$ of various concentrations using a consolidation test.

\section{MATERIALS AND METHODS}

\section{Materials}

Various mixtures of basalt soil and bentonite in a proportion of 100:20 by dry weight were used. Basalt soil was collected from Uwaba plateau of Saga prefec- ture, Japan. Study was conducted on the mixtures of basalt soil with four different bentonites. For the sake of simplicity these bentonites named as Bentonite-A, B, C and $\mathrm{D}$. The properties of all the four bentonites are tabulated in Table 1.

\section{Permeant liquids}

The earlier study by the author (Mishra et al, 2005) demonstrated that a concentration less than $0.1 \mathrm{~mol}_{\mathrm{c}} / \mathrm{L}$ of $\mathrm{NaCl}$ and $\mathrm{CaCl}_{2}$ solution has insignificant effect on the behaviour of the mixtures of basalt soil and bentonite including the liquid limit, hydraulic conductivity and compressibility. Hence in the present study tests were carried out using the $\mathrm{NaCl}$ and $\mathrm{CaCl}_{2}$ solutions of $0,0.1$, and $1 \mathrm{~mol}_{\mathrm{c}} / \mathrm{L}$ concentration on the mixtures. Solutions were prepared by dissolving salt of $\mathrm{NaCl}$ and $\mathrm{CaCl}_{2}$ (powdered with purity grade of $>95 \%$ ) in deionized water. Each solution was mixed in $1 \mathrm{~L}$ flask. Ion chromatograph was used to measure the actual concentrations of $\mathrm{Na}^{+}$and $\mathrm{Ca}^{2+}$ present in the permeant solution. The result of the chemical analysis is tabulated in Table 2.

\section{Physical and Chemical properties of mixtures}

The grain size distribution of the basalt soil was obtained by the dry sieving whereas the particle size distribution was obtained by hydrometer analysis as per ASTM D 422. According to the test result $70.5 \%$ of the particles of basalt soil are less then $75 \mu \mathrm{m}$ in diameter. The liquid limit of the mixtures was determined by both the Casagrande's method (ASTM D 4318) and falling cone method (BS 1377) by adding salt solutions with different concentration to dried soil mixtures.

Table 2. Properties of permeant liquid.

\begin{tabular}{|c|c|c|c|c|}
\hline \multirow{3}{*}{$\begin{array}{l}\text { Target salt } \\
\text { Concentration } \\
\left(\mathrm{mol}_{\mathrm{c}} \mathrm{L}\right)\end{array}$} & \multicolumn{4}{|c|}{ Measured solute concentrations $(\mathrm{g} / \mathrm{L})$} \\
\hline & \multicolumn{2}{|c|}{$\mathrm{NaCl}$ Solution } & \multicolumn{2}{|c|}{$\mathrm{CaCl}_{2}$ Solution } \\
\hline & $\mathrm{Na}^{+}$ & $\mathrm{Ca}^{2+}$ & $\mathrm{Na}^{+}$ & $\mathrm{Ca}^{2+}$ \\
\hline 1 & 22.7 & 0.9 & 0.006 & 21.1 \\
\hline 0.1 & 2.2 & 1.3 & 0.002 & 1.6 \\
\hline
\end{tabular}

Table 1. Properties of bentonites.

\begin{tabular}{lcccc}
\hline \multicolumn{1}{c}{ Properties } & $\begin{array}{c}\text { Bentonite A } \\
\text { (Hotaka) }\end{array}$ & $\begin{array}{c}\text { Bentonite B } \\
\text { (Super clay) }\end{array}$ & $\begin{array}{c}\text { Bentonite C } \\
\text { (Kunigel VAS) }\end{array}$ & $\begin{array}{c}\text { Bentonite D } \\
\text { (Premium gel) }\end{array}$ \\
\hline${ }^{+}$Liquid limit (\%) & 310.5 & 615.5 & 391.4 & 511.2 \\
${ }^{+}$Plastic Limit (\%) & 54.1 & 47.6 & 57.2 & 43.9 \\
${ }^{+}$Activity & 4.18 & 6.86 & 4.83 & 6.31 \\
${ }^{+}$Specific gravity & 2.54 & 2.46 & 2.53 & 2.51 \\
${ }^{+}$Clay (<2 $\mu$ m) content & 61.4 & 82.8 & 69.2 & 74.1 \\
${ }^{+}$Cation Exchange Capacity & 52.8 & 72.3 & 61.0 & 92.4 \\
(cmol/kg) & & & & \\
${ }^{*}$ Exchangeable cation (cmolc/kg) & & 19.1 & 42.2 & 21.5 \\
$\mathrm{Ca}^{2+}$ & 74.3 & 9.6 & 2.2 & 6.7 \\
$\mathrm{Mg}^{2+}$ & 7.5 & 45.4 & 63.6 & 58.9 \\
$\mathrm{Na}^{+}$ & 47.0 & 1.0 & 1.3 & 1.7 \\
$\mathrm{~K}^{+}$ & 5.6 & & & \\
\hline
\end{tabular}

${ }^{+}$Data provided by Hojun Co., Ltd., Japan, *Determined by $\mathrm{CH}_{3} \mathrm{COONH}_{4}$ method 
The compaction curves (i.e. water content vs dry density relationship) for the mixture of basalt and bentonite was determined by adding DI water in accordance with the standard proctor test described in ASTM standard D 698.

\section{Free swell test}

The free swell test was conducted according to ASTM D 5890 for DI water and 0.1 and 1 mol/l concentration of $\mathrm{NaCl}$ and $\mathrm{CaCl}_{2}$. Approximately $90 \mathrm{~mL}$ of $\mathrm{DI}$ water or salt solution was poured into a $100 \mathrm{~mL}$ graduated cylinder. Two grams of dry powdered bentonite was placed in the salt solution in the cylinder in $0.1 \mathrm{~g}$ increments. Then the cylinder was rinsed with salt solution or DI water and was filled up to the $100 \mathrm{~mL}$ mark. After $24 \mathrm{~h}$ of exposure the swollen volume of the bentonite was measured.

\section{Consolidation test and determination of hydraulic conductivity}

Consolidation tests were carried out to determine the hydraulic conductivity of the samples. The tests were carried out on the sample of $60 \mathrm{~mm}$ diameter and $20 \mathrm{~mm}$ thickness according to ASTM D 2435 using standard consolidometers. The samples were prepared by adding $\mathrm{NaCl}$ and $\mathrm{CaCl}_{2}$ solutions of different concentrations to the basalt soil and bentonite mixtures, and the initial water content of the samples was adjusted to the liquid limit. The inside of the ring was smeared with a very thin layer of silicon grease in order to avoid friction between the ring and soil sample. Filter paper was placed at the bottom and top of the sample. A top cap with a porous stone was placed above the soil sample. The entire assembly was placed in the consolidation cell and positioned in the loading frame. The consolidation ring was immersed in the liquid with the same composition as the saturating fluid, and the entire consolidation cell was enclosed within a plastic bag to reduce evaporation. Then the consolidation cells were allowed to equilibrate for $24 \mathrm{~h}$ prior to commencing the test. All the samples were initially loaded with a stress of $4.9 \mathrm{kPa}$, increasing by an increment ratio of 1 (i.e. 4.9, 9.8, 19.6, $39.2 \mathrm{kPa}$...etc) to a maximum pressure of $1256 \mathrm{kPa}$.

\section{Determination of hydraulic conductivity}

For each pressure increment the change in the thickness of soil sample was measured from the readings of the dial gauge. Then the change in the void ratio corresponds to an increase in the overburden pressure was calculated by the equation 1 ,

$$
\Delta e=\frac{\Delta H}{H}
$$

Where, $\Delta H=$ Change in the thickness of sample due to increase in pressure

$$
H=\text { Initial thickness of the sample }
$$

From the consolidation test result, a time-settlement curve was obtained at each pressure increment. The coefficient of consolidation $c_{r}$ was obtained using Taylor's square root time $(\sqrt{T})$ method.

The co-efficient of volume change can be calculated by the formula,

$$
m_{r}=\frac{\alpha_{i}}{1+e}
$$

where $\alpha_{r}=$ coefficient of compressibility

$$
\begin{aligned}
=\frac{\Delta e}{\Delta \sigma} \quad \text { where, } \\
\Delta \sigma=\text { Change in pressure } \\
\Delta e=\text { Change in void ratio }
\end{aligned}
$$

The coefficient of permeability, $k$, was calculated using the equation- 3 for various pressure increments using the $c_{v}$, and coefficient of volume change, $m_{v}$.

$$
\begin{aligned}
& k=c_{v} m_{v} \gamma_{w}, \\
& \text { where, } \gamma_{w} \text { is the unit weight of the pore fluid }
\end{aligned}
$$

\section{RESULTS AND DISCUSSION}

\section{Liquid Limit}

The effect of the pore water on the liquid limit of the mixtures is shown in Table 3. The liquid limit of the mixtures is seen to decrease with increasing salt concentration. For a given concentration, the $\mathrm{NaCl}$ salt solution gives a higher liquid limit than the $\mathrm{CaCl}_{2}$ solution. This trend was quite consistent with diffuse double layer theory. Interparticle forces have a more prominent role in determining the liquid limit. The distance between particles or between structural units of the particles is such that the forces of interaction between the clay particles become sufficiently weak to allow easy movement of particle relative to each other. The soils are

\begin{tabular}{|c|c|c|c|c|c|c|c|c|}
\hline \multirow{3}{*}{$\begin{array}{c}\text { Salt } \\
\text { concentration } \\
\left(\mathrm{mol}_{\mathrm{e}} / \mathrm{L}\right)\end{array}$} & \multicolumn{8}{|c|}{ Mixture of basalt with different bentonites (in 100:20 proportion) } \\
\hline & \multicolumn{2}{|c|}{ with bentonite- $\mathrm{A}$} & \multicolumn{2}{|c|}{ with bentonite-B } & \multicolumn{2}{|c|}{ with bentonite-C } & \multicolumn{2}{|c|}{ with bentonite-D } \\
\hline & $\mathrm{NaCl}$ & $\mathrm{CaCl}_{2}$ & $\mathrm{NaCl}$ & $\mathrm{CaCl}_{2}$ & $\mathrm{NaCl}$ & $\mathrm{CaCl}_{2}$ & $\mathrm{NaCl}$ & $\mathrm{CaCl}_{2}$ \\
\hline $0(\mathrm{DW})$ & 78.4 & - & 140.5 & - & 92.7 & - & 118 & - \\
\hline 0.1 & 68.5 & 67 & 103.8 & 81.8 & 72.4 & 67.5 & 88.5 & 69.2 \\
\hline 1 & 63.3 & 63 & 73.5 & 73.3 & 62.7 & 61.3 & 62.3 & 61.3 \\
\hline
\end{tabular}
water saturated at this point, and the cohesion between particles in remoulded sample is small. In high swelling clays such as montmorillonite, the dominant interparticle force is one of repulsion. This force of repulsion determines the distance between particles. Therefore

Table 3. Liquid limit for the different salt concentrations for the mixtures of basalt soil and various bentonites. 
an increase in the salt concentration or substitution of divalent for monovalent exchangeable cation decreases the inter-particle repulsion. As a result the particle becomes free to move at lower water contents or lower inter-particle distances, and the liquid limit decreases (Warkentin, 1961).

Table 3 also shows that the decrease in the liquid limit due to the increase in the salt concentration is small for a range of 0.1 to $1 \mathrm{~mol}_{\mathrm{c}} / \mathrm{L}$ than for the range of 0 to $0.1 \mathrm{~mol} / \mathrm{L}$. An increase in the $\mathrm{CaCl}_{2}$ concentration from 0 to $0.1 \mathrm{~mol}_{\mathrm{c}} / \mathrm{L}$ produced a large decrease in the liquid limit compared to $\mathrm{NaCl}$ solution. A further increase in the $\mathrm{CaCl}_{2}$ concentration did not produce any significant decrease in the liquid limit.

A comparison of the liquid limit of the mixtures show that, the mixture with bentonite-B possess the highest liquid limit which can be attributed to the clay fraction percentage, i.e. a large surface area (Bojana $e t$ al 2004, Muhantham 1991). The change in the liquid limit due to the salt concentration was higher for the bentonites with higher initial liquid limit before addition of salt. The mixture with Bentonite-B exhibited a highest reduction in the liquid limit by adding salt solution.

\section{Free swell}

The effect of $\mathrm{NaCl}$ and $\mathrm{CaCl}_{2}$ concentrations on free swelling for the four pure bentonites is shown in Table 4. At the equal concentration higher swelling was observed for $\mathrm{NaCl}$ compared to $\mathrm{CaCl}_{2}$ solutions. For $\mathrm{NaCl}$ solutions osmotic as well as hydration swelling takes place which allows the interlayer spacing to become large, resulting in greater swelling. On the other hand only hydration swelling takes place for $\mathrm{CaCl}_{2}$ solutions (Norrish and Quirk, 1954; Zhang et al, 1995). With increasing the salt concentration, the swell volume decreases. When the cation concentration in the bulk solution increases, water leave the interlayer region due to the gradient of free energy induced by the elevated concentration in the bulk pore water.

A significant reduction in swelling took place when the salt concentration was increased from 0.1 to $1 \mathrm{~mol}_{\mathrm{c}} / \mathrm{L}$. At $1 \mathrm{~mol} / \mathrm{L}$ of the $\mathrm{NaCl}$ and $\mathrm{CaCl}_{2}$ solution nearly equal swelling was observed for all bentonites. The decrease in the swelling by the increase of the concentration from 0 to $0.1 \mathrm{~mol} / \mathrm{L}$ was higher for $\mathrm{CaCl}_{2}$ than for $\mathrm{NaCl}$.

Comparison of the swelling for the bentonites show that bentonite-A with the highest amount of exchange- able calcium exhibits the least swelling in water. The bentonite-B and $\mathrm{D}$ with an equal exchangeable sodium percentage (ESP) (i.e. 60 and $66 \%$ respectively) exhibits the same amount of swelling. For bentonite-C with an ESP of $58 \%$ less swelling occurred compared to bentonite $B$ and $D$. The less swelling of bentonite- $C$ can be attributed to presence of a higher amount of exchangeable calcium. Data from the table also shows that there is a significant reduction in the swelling occurred when the $\mathrm{CaCl}_{2}$ concentration increased from 0.01 to $0.1 \mathrm{~mol}_{\mathrm{c}} / \mathrm{L}$. On the other hand the swelling decreased significantly with increasing the $\mathrm{NaCl}$ concentration from 0.1 to $1 \mathrm{~mol}_{c} / \mathrm{L}$. These two findings show that a higher salt concentration of $\mathrm{NaCl}$ is required to replace the exchangeable cations as compare to $\mathrm{CaCl}_{2}$ solution. This is due to the higher valency of calcium which replaces the monovalent exchangeable cation easily compared to sodium ion.

\section{Hydraulic conductivity}

Hydraulic conductivity of the mixtures was calculated for various pressure increments using experimentally determined values of $c_{v}$ and $m_{v}$. Figure 1 show the relationship between the void ratio and hydraulic conductivity $(k)$ at different $\mathrm{NaCl}$ and $\mathrm{CaCl}_{2}$ concentrations for the four different mixtures. It can be seen that $\log k$ varied approximately linearly with the void ratio. Similar observation has been reported by other investigators (Olson and Daniel, 1981; Pandian et al, 1995) for the samples permeated with pure water. Each of the plots shows that the $k$ decreases with decreasing void ratio. Anisotropic consolidation of the samples causes reorientation of the clay platelets into a plane perpendicular to the direction of the major principle stress and there by increases the tortuosity factor (Quigley et al, 1966) which results in the reduction in $k$. The compression of the soil sample in the consolidation cell due to increase in the overburden pressure resembles the compression of the liner material caused by increase in the overburdened waste. Hence the hydraulic conductivity of the liner decreases by an increase of the tortuosity factor induced by the increase of the overburden waste.

Comparison of the figures shows that $\mathrm{Ca}$-soil exhibits a higher $k$ values than $\mathrm{Na}$-soil at a given concentration for a particular sample. However the $k$ was almost identical at $1 \mathrm{~mol}_{\mathrm{c}} / \mathrm{L}$ concentration for both $\mathrm{NaCl}$ and $\mathrm{CaCl}_{2}$ solution. Jo et al. (2001) had also reported similar observation. Similar observation for the liquid

Table 4. Free swelling for the different bentonites at various salt concentrations.

\begin{tabular}{|c|c|c|c|c|c|c|c|c|}
\hline \multirow{3}{*}{$\begin{array}{c}\text { Salt } \\
\text { concentration } \\
\left(\mathrm{mol}_{\mathrm{c}} / \mathrm{L}\right)\end{array}$} & \multicolumn{8}{|c|}{ Free swell for pure bentonite $(\mathrm{mL} / 2 \mathrm{~g})$} \\
\hline & \multicolumn{2}{|c|}{ Bentonite-A } & \multicolumn{2}{|c|}{ Bentonite-B } & \multicolumn{2}{|c|}{ Bentonite- $\mathrm{C}$} & \multicolumn{2}{|c|}{ Bentonite-D } \\
\hline & $\mathrm{NaCl}$ & $\mathrm{CaCl}_{2}$ & $\mathrm{NaCl}$ & $\mathrm{CaCl}_{2}$ & $\mathrm{NaCl}$ & $\mathrm{CaCl}_{2}$ & $\mathrm{NaCl}$ & $\mathrm{CaCl}_{2}$ \\
\hline $0(\mathrm{DW})$ & 14 & - & 25 & - & 21 & - & 24 & - \\
\hline 0.01 & 13 & 12 & 22 & 21 & 20 & 18 & 22 & 19 \\
\hline 0.1 & 12 & 9 & 20 & 13 & 16 & 10 & 20 & 11 \\
\hline 1 & 7 & 7 & 8 & 8 & 6 & 6 & 8 & 7 \\
\hline
\end{tabular}



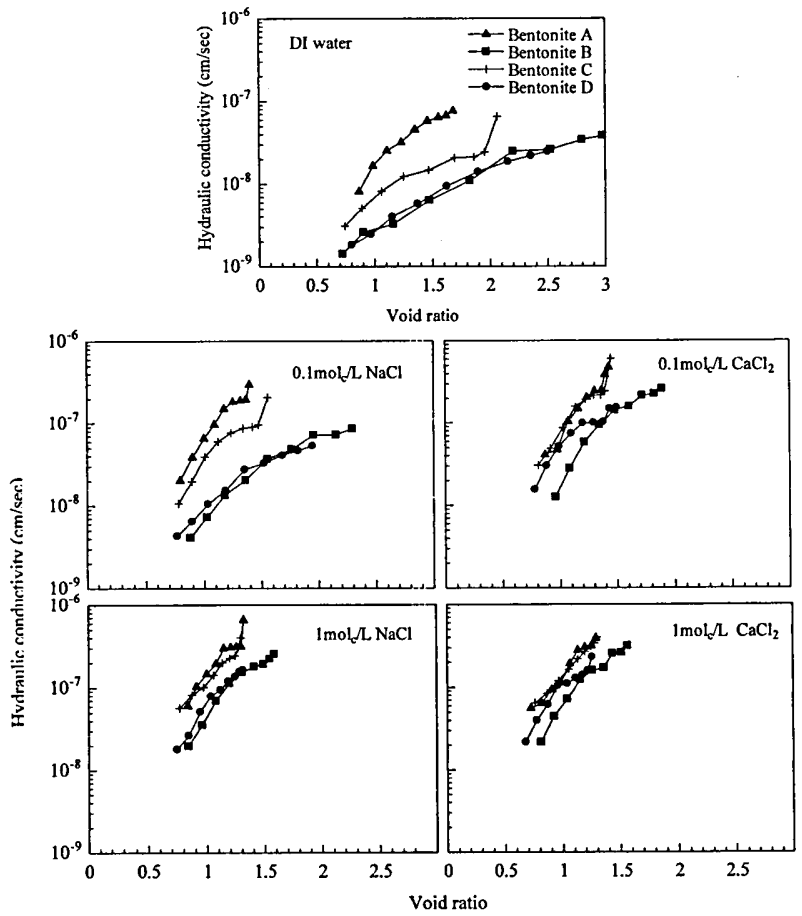

Fig. 1. Plots for the hydraulic conductivity versus void ratio at various concentration of $\mathrm{NaCl}$ and $\mathrm{CaCl}_{2}$ for the mixtures of basalt and various bentonites.

limit as well as the free swell at 1 mol/L concentration was also observed. All figures indicate that the $k$ changed significantly when the concentration increased from 0 to $0.1 \mathrm{~mol}_{\mathrm{c}} / \mathrm{L}$ and this change was more pronounced for $\mathrm{CaCl}_{2}$ than for $\mathrm{NaCl}$. The results for all the mixtures show that increase of the concentration from 0 to $0.1 \mathrm{~mol} / \mathrm{L}$ increased the $k$ by 2 to 4 times for $\mathrm{NaCl}$ solution, while increased in $k$ for $\mathrm{CaCl}_{2}$ by 6 to 14 times. However with further increasing the concentration from 0.1 to $1 \mathrm{~mol}_{\mathrm{c}} \mathrm{L}, k$ increased by only 1.1 to 1.7 times for $\mathrm{CaCl}_{2}$ but 3 to 5 times for $\mathrm{NaCl}$. Similar behavior was also observed for the liquid limit as well as for the free swelling of the bentonites.

Comparison of the different bentonites for a particular salt concentration shows the sample with higher liquid limit has a lower $k$. The mixture with bentonite- $\mathrm{B}$ which has the highest liquid limit exhibited lowest $k$ while for the mixtures with bentonite-A, which has a lower liquid limit exhibited highest $k$ for all the salt concentration range. However with increasing the salt concentration, the liquid limit for all the mixtures converges and so the $k$. It is also observed that for same concentration the difference in $k$ for all the mixture for $\mathrm{CaCl}_{2}$ is less compared with $\mathrm{NaCl}$.

\section{Comparison of $k$ for different bentonites at a given void ratio}

Figures $2 \& 3$ show the salt concentration versus hydraulic conductivity at the void corresponding to the maximum dry density and optimum moisture content prepared from Figure 1. Figures shows that increase in the salt concentration enhance the $k$ of the samples. This increase was quite prominent for $\mathrm{CaCl}_{2}$ compared

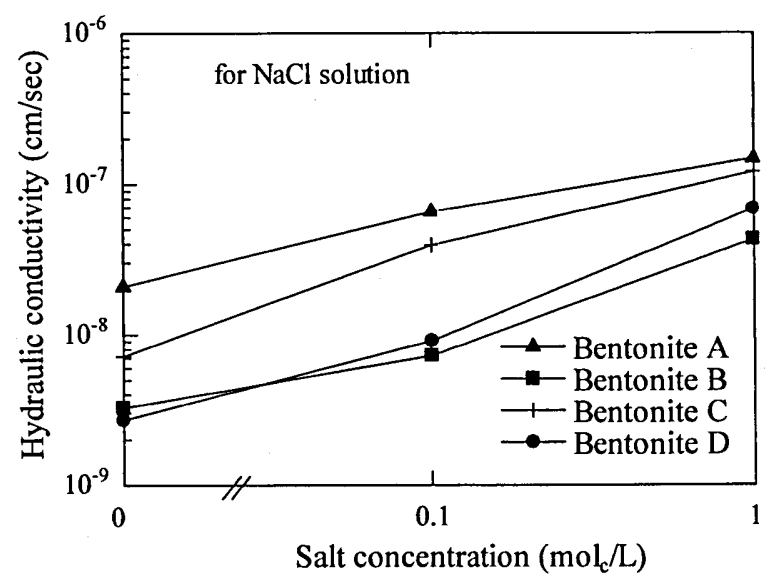

Fig. 2. Plot for hyadraulic conductivity and void ratio for the mixture of basalt and different betnonites for different concentration of $\mathrm{NaCl}$ at void ratio corresponds to the maximum dry density.

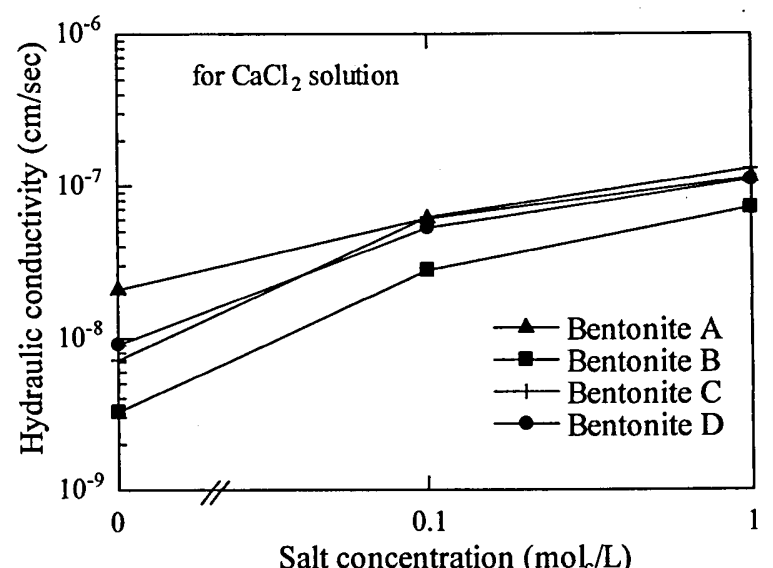

Fig. 3. Plot for hyadraulic conductivity and void ratio for the mixture of basalt and different betnonites for different concentration of $\mathrm{CaCl}_{2}$ at void ratio corresponds to the maximum dry density.

to $\mathrm{NaCl}$ solution. Comparison for the different concentration of $\mathrm{NaCl}$ shows that $k$ for the mixture containing bentonite-D increased to a large extent as comparison to other. The $k$ increased 25 times when the $\mathrm{NaCl}$ concentration increased from 0 to $1 \mathrm{~mol}_{\mathrm{c}} \mathrm{L}$ for the mixture with bentonite-D. However the corresponding increase was only 7 times for the mixture with bentonite-A. Similar comparison for the different concentration of $\mathrm{CaCl}_{2}$ shows that an increase in the concentration from 0 to $1 \mathrm{~mol}_{\mathrm{c}} \mathrm{L}$ enhanced the $k$ for the mixture with bentonite $\mathrm{D}$ by 40 times, which was the highest among the mixtures. Similarly mixture with bentonite-A showed a marginal increase in the $k$. The higher change in the $k$ for the bentonite-D is due to its higher ESP and cation exchange capacity.

\section{SUMMARY AND CONCLUSION}

Consolidation test was performed on the various mixtures of basalt soil and bentonite in the proportion of 100:20 by dry weight to evaluate the effect of salt on the 
hydraulic conductivity of the mixtures. The results demonstrated that the salt concentration has a pronounced effect on the hydraulic conductivity of the mixtures.

When the salt concentration was increased from 0 to $0.1 \mathrm{~mol} / \mathrm{L}$, the change in the $k$ was significant which was more pronounced in $\mathrm{CaCl}_{2}$ than $\mathrm{NaCl}$. An increase of the concentration from 0 to $0.1 \mathrm{~mol}_{\mathrm{c}} / \mathrm{L}$ raised $k$ by 2 to 4 times for $\mathrm{NaCl}$ solution whiles 6 to 14 times for $\mathrm{CaCl}_{2}$ in all the mixtures. For a particular salt concentration the mixture with a higher liquid limit exhibited a lower $k$. However with increasing the salt concentration the difference between the liquid limit as well as $k$ for all four mixtures reduced. When the $k$ for the mixtures with different bentonites is compared at the same salt concentration the mixture containing the bentonite with a higher liquid limit showed a lower $k$. There is less difference in the $k$ of the mixtures for the higher salt concentration. The difference in the $k$ of the mixtures at the same concentration is smaller for $\mathrm{CaCl}_{2}$ than for $\mathrm{NaCl}$.

\section{REFERENCES}

ASTM 2002 Standard Test Method for Particle-Size Analysis of Soils, D 422-63: Philadelphia, American Society for Testing and Materials.

ASTM $2000 \quad$ Standard Test Methods for Laboratory Compaction Characteristics of Soil Using Standard Effort, D 698: Philadelphia, American Society for Testing and Materials.

ASTM 2000 Standard Test Methods for Liquid Limit, Plastic Limit, and Plasticity Index of Soils, $D$ 4318: Philadelphia, American Society for Testing and Materials.

ASTM 1996 Standard Test Method for One-Dimensional Consolidation Properties of Soils, D 2435: Philadelphia, American Society for Testing and Materials.

ASTM 1996 Standard Test Method for One-Dimensional Consolidation Properties of Soils, D 2435: Philadelphia, American Society for Testing and Materials.

ASTM 2001 Standard Test Method for Swell Index of Clay Mineral Component of Geosynthetic Clay Liners, $\mathbf{D} \mathbf{5 8 9 0}$ : Philadelphia, American Society for Testing and Materials.

British Standards 1990 Methods of test for soils for civil engineering purposes: classification tests 1377-2

Bojana, D. and Ludvik, T 2004 Liquid limit and specific surface of clay particles. Geotechnical Testing Journal, 27(6): $580-584$

Bolt, G. H. 1956 Physico-chemical analysis of the compressibility of pure clays. Geotechnique, 6(1): 86-93

Budhu, M. 1991 The permeability of the soils with organic fluids. Canadian Geotechnical Journal 28: 140-147

Casagrande, A. and Fadum, R. E. 1944 Notes on soil testing for engineering purposes Soil Mech. Series No. 8 Harvard Graduate School of Engineering.

Daniel, D. 1994 State-of-the-art: Laboratory hydraulic conductivity tests for saturated soils. Hydraulic conductivity and waste contaminant transport in the soil, STP 1142: D. Daniel and S. Trautwein, eds., ASTM, West Conshohocken, Pa., 30-78

Gleason, M., Daniel, D. E. and Eykholt, G. R. 1997 Calcium and sodium bentonite for hydraulic containment applications. Journal of Geotechnical and Geoenvironmental Engineering ASCE, 123(5): 438-445

Ho Young Jo, Takeshi Katsumi, Craig H. Benson and Tuncer B. Edil 2001 Hydraulic conductivity and swelling of nonprehydrated GCLs permeated with single-species salt solutions. Journal of Geotechnical and Geoenvironmental Engineering ASCE, 127(7): 557-567

Madsen, F. T. 1994 Clays and synthetic liners-durability against pollutant attack. In Proceedings of the $13^{\text {th }}$ International Conference on Soil Mechanics and Foundation Engineering, New Delhi, 5: 287-288

Mathew, K. and Narasimha Rao, N. 1997 Influence of cations on compressibility behavior of a marine clay. Journal of Geotechnical and Geoenvironmental Engineering ASCE, 123(11): 1071-1073

Mesri, G., and Olsen, R. E 1971 Mechanisms controlling the permeability of clays. Clay and Clay Minerals, 19: 151-158

Mesri, G., and Olsen, R. E 1971 Consolidation characteristics of montmorillonite. Geotechnique 21(4): 341-352

Mishra, A. K., Ohtsubo, M., Li, L., Higashi, T., 2005 Effect of salt concentrations on the permeability and compressibility of soil-bentonite mixtures. Journal of the faculty of agriculture, Kyushu university $\mathbf{5 0 ( 2 ) : ~ I n ~ p r e s s ~}$

Mitchell, J. K. and Madson, F. T., 1987 Chemical effects on the clay hydraulic conductivity In Geotechnical practice for waste disposal. American Society for Civil Engineers, New York, 87-116

Mitchell, J. K. 1976 Fundamentals of Soil Behavior John \& Wiley \& Sons, Inc., New York

Newland, P. L., and Alley, B. H. 1960 A study of consolidation characteristics of a clay. Geotechnique, 10: $62-74$

Muhantham, B. 1991 Liquid limit and surface area of clays. Geotechnique 41(1): 135-138

Norrish, K. and Quirk, J. 1954 Crystalline swelling of montmorilIonite; use of electrolyte to control swelling. Nature, 173: 255- 257

Ohtsubo, M. Loretta, Y. Li, Yamaoka, S, Higashi, T 2004 Leachibility of heavy metals and salt from bottom ash, $5^{\text {th }}$ Geoenvironmental Engineering Symposium, Japanese Geotechnical Society, 169 174

Olson, R. E., and Daniel, D. E. 1981 Measurement of hydraulic conductivity of fine grained soils. In Permeability and ground water contaminant transport, American Society for Testing and Materials, Special Technical Publication STP 746, 18-60

Olson, R. E., and Mesri, G. 1970 Mechanism controlling compressibility of clays. ASCE, Journal of Soil Mechanics and Foundation Division, 96(6): 1863-1878

Pandian, N. S., Nagaraj, T. S., and Narasimha Raju, P. S. R. 1995 Permeability and compressibility behaviour of bentonite-sand/soil mixes. Geotechnical Testing Journal, 18(1): 86-93

Petrov, R. J., and Rowe, R. K. 1997 Geosynthetic clay liner (GCL) chemical compatibility by hydraulic conductivity testing and factors impacting its performance. Canadian Geotechnical Journal, 34: 863-885

Quigley, R. M and Thompson, C. D. 1966 The fabric of anisotropically consolidated sensitive marine clay. Canadian Geotechnical Journal, 3(2): 61-73

Quirk, J. P., and Schofield, R. K. 1955 The effect of electrolyte concentration on soil permeability. Journal of Soil Science, 6(2): 163-178

Ruhl, J. L., Daniel D. E. 1997 Geosynthetic clay liners permeated with chemical solutions and leachate. Journal of Geotechnical and Geoenvironmental Engineering ASCE, 123(4): 369-381

Sivapullaiah, P. V., Sridharan, A. and Stalin, V. K. 2000 Hydraulic conductivity of bentonite-sand mixtures. Canadian Geotechnical Journal, 37: 406-413

Sridharan, A. and Rao, G. V. 1973 Mechanism controlling volume change of saturated clay and the role of effective stress concept. Geotechnique 23(3): 359-382

Studds, P. G, Stewart, D. I and Cousen, T. W. 1998 The effect of salt solutions on the properties of bentonite-sand mixtures. Clay Minerals 33: $651-660$

Taylor, D. W 1942 Research on consolidation of clays, Serial 82, Massachusetts Institute of Technology, Department of 
Civil Engineering, Cambridge

Terzaghi, K. T. 1923

Durchlassigkeitsziffer des Tons aus dem Verlauf der hydrodyanamischen Spannungserscheinungen, Akademia der Wissenschaften in Wien. Sitzungsberichte, Mathematischnaturwissenschaftliche Klasse-IIa, 132: 125-138

Van Olphen, H 1963 An Introduction to Clay Colloid Chemistry. $2^{\text {nd }}$ edition, Interscience publishers, New York

Warkentin, B. P. 1961 Interpretation of the upper plastic limit of clays. Nature, 190: 287-288

Yong, R. N., Sheremata, T. W. 1991 Effect of chloride ions on adsorption of cadmium from a landfill leachate. Canadian Geotechnical Journal, 28: 378-387

Zhang, F., Low, P. and Roth, C. 1995 Effects of monovalent exchangeable cations and electrolytes on the relation between swelling pressure and interlayer distance in montmorillonite. Journal of Colloid Interface Science, 173: 34-41 